\title{
Az államfő testőrségei az Osztrák-Magyar Monarchiában
}

Az Osztrák-Magyar Monarchia dualisztikus államalakulat volt, amelyben két szuverén állam az Osztrák Császárság és a Magyar Királyság bizonyos ügyeit közösen intézte. Ez az állítás megfelel ugyan a történelemtudomány 2010. évi ismereteinek, illetve a korabeli gyakorlatnak. Nem szabad azonban elfeledkezni arról, hogy a kiegyezésnek a maga korában két féle értelmezése volt.

A HABSBURG-dinasztiához közel álló körök úgy szerették volna értelmezni a kiegyezést, hogy a dualisztikus államalakulat olyan ország, ahol a birodalom két felében bizonyos helyi ügyeket önállóan intéznek ugyan, azonban az államalakulat egészének a kormányzása az uralkodót illeti meg.

Ezzel szemben a kiegyezés magyar felfogása szerint a birodalom két független ország szövetsége, amelyben egyes ügyeket közösen intéznek. A gyakorlatban a magyar felfogás érvényesült. A kiegyezéskor azonban ez még nem volt mindenki számára egyértelmü. Ezt tükrözte az államalakulat két féle elnevezése is. Mindkét elnevezés használatát uralkodói utasítás tette lehetővé. Nevezetesen:

- „Osztrák-Magyar Monarchia” (Österreichisch-Ungarische Monarchie)

- „Osztrák-Magyar Birodalom” (Österreichisch-Ungarisches Reich) ${ }^{\mathbf{1}}$

A dualizmus, mint fogalom jelen esetben Ausztria és Magyarország viszonyrendszerét jelöli, amelyet a kiegyezési törvények szabályoztak. A kiegyezési törvények azonban magukban foglalták az uralkodói hatalom és az alkotmányosság szerepének szabályozását is. ${ }^{2}$

Témánk szempontjából azért fontos a közös érdekü viszonyok — vagy ahogyan az osztrák kiegyezési törvény fogalmaz a közös ügyek témája — mert annak tisztázása által helyezhető el a testőrségek feladatköre az Osztrák-Magyar Monarchia struktúrájában. A közös érdekü viszonyokat a magyar kiegyezési törvény az osztráknál részletesebben szabályozta. A magyar kiegyezési törvényben foglalt témák négy csoportba tartoznak.

1. Az uralkodói udvartartás.

2. A Pragmatica Sanctio-ból származó közös ügyek. Ezért ezen ügyeket pragmatikus ügyeknek is nevezték. Ide tartozott a külügy, a hadügy és ezek finanszírozására hivatott pénzügy.

3. A hitelügy. Ide tartoztak a korábbi államadósságok is.

4. A vám- és kereskedelmi szövetség és azon közös érdekü viszonyok, amelyeknél fenn állt ugyan a közös rendezés lehetősége, azonban az egyeztetés eredménytelensége esetén a két társország önálló intézkedésre is jogosult volt. Ide tartoztak a gazdasági szerződések külállamokkal, a közvetett adózás, a vasút-, hajózás- és postaügyek összehangolása, valamint a pénzrendszer és jegybank. Ezen ügyek csoportját dualisztikus ügyeknek is nevezték. ${ }^{3}$

Témánk tekintetében az uralkodói udvartartás és a pragmatikus, ügyek közül a hadügy érdekes.

Az uralkodói udvartartás témája ugyan szerepel a közös ügyek között, azonban csupán a magyar kiegyezési törvényben. Az osztrák kiegyezési törvény nem is foglalkozott az udvartartás kérdésével.

A magyar kiegyezési törvényben is úgy szerepel az udvartartás, mint ami nem tartozik a közös ügyek közé. Joggal merülhet fel a kérdés, hogy akkor miért kellett egyáltalán megemlíteni ezt a témát a kiegyezési törvényben? Egyértelmü, hogy a magyar fél ezzel is hangsúlyozni kívánta a kiegyezés magyar felfogását. Nevezetesen, hogy a kiegyezés eredményeként a monarchia két külön országból áll. Két ország kapcsolatáról van szó, ahol az udvartartás sem közös, még akkor sem, ha a két állam legfőbb közjogi méltóságát egy személy tölti be.

Nem véletlenül hangsúlyozták a kortársak Magyarország szuverenitását és igyekeztek azt kidomborítania két birodalomrész viszonyát szabályozó magyar törvényben. Az 1848/1849-es forradalom és szabadságharcot cári segédlettel vérbe fojtó HABSBURG hatalom ugyanis a „Verwirkungstheorie” (az úgynevezett jogeljátszás elmélet) létrehozásával igyekeztek elméleti alapot teremteni annak, hogy a magyar államot felszámolták. A hg. Karl SCHWARZENBERG -től származó jogeljátszás elméletet a SCHMERLING-rezsim ismét előtérbe helyezte. ${ }^{4}$

Függetlenül azonban attól, hogy az udvartartás nem tartozott a közös ügyek közé a magyar fél a magyar király udvartartási költségét mindig az osztrák császár udvartartási költségeivel azonos összegben állapította meg. Ebben a tekintetben nem követték a közös költségek két állam közötti elosztásának azon elvét, amely a két társország gazdasági erejét kifejező kvótát tekintette a közös terhek megosztási arányának. (I.sz. melléklet)

A hadügy témája azért érdekes, mivel a császár és a király testőrségeinek személyi állománya egyaránt a haderőből kapta utánpótlását. Az Osztrák-Magyar Monarchia fegyveres ereje a hadseregből a haditengerészetböl, valamint - a hadseregen belül, a közös hadsereg mellett szervezett honvédségből és Landwehr-böl állt, amelyhez háború időszakában a népfelkelö és Landsturm 
alakulatok kapcsolódtak. A fegyveres erő egészére érvényesült az uralkodó vezérleti, vezényleti és belszervezeti joga, a Magyar Királyi Honvédség tekintetében megkötésekkel és minisztériumi ellenjegyzéssel. ${ }^{5} \mathrm{~A}$ haditengerészet és a közös hadsereg, valamint a honvédség rendelkezett elkülönült tisztképző intézményekkel. A közös hadsereg vezérkari tisztképző intézménnyel is rendelkezett. ${ }^{6}$ Ezen intézményekben avatott tisztek közül került ki a testőrségek személyzetének tiszti állománya.

Az Osztrák-Magyar Monarchiában összesen hat testör szervezet müködött. Az osztrák császárt négy a magyar királyt pedig két testőr szervezet védelmezte függetlenül attól hogy, a két közjogi méltóságot egy személy töltötte be. A testőrségek természetesen nem csupán az uralkodót, hanem annak közvetlen környezetét is védelmezték.

Császári testőrségek voltak: a Császári Alabárdos Testörség (89 fö) a Császári Darabont Testörség (65 fö), a Császári Lovas Testörség (140fö), a Császári Gyalogos Testörség (286f”).

Királyi testörségek voltak: a Magyar Királyi Nemesi Testörség (92 fö), a Magyar Királyi Darabont Testörség (53 fö).

2010.XII.31. a Köztársasági Őrezred meglehetősen sokszínű feladatköre közé tartozó teendők egy részét a dualizmus időszakában külön testületek látták el. Elődeink úgy gondolták, hogy a magyar államiságot szimbolizáló koronázási jelvények, valamint az országgyủlés védelmét nem helyes, ha a végrehajtó hatalmat gyakorló kormánynak alárendelt egyik rendvédelmi testület alakulata, látja el. Ebből fakadóan - a magyar hagyományokkal összhangban - külön Magyar Királyi Koronaörség (58 fö) müköködött. ${ }^{8}$ A koronaörség a koronaörök alárendeltségébe tartozott. A koronaőröket az országgyűlés az államfővel egyetértésben kérte fel. Az országgyülés biztonságát pedig a Magyar Királyi Képviselőházi Örség (58 fő vigyázta. ${ }^{9}$ A képviselőházi örség a házelnök felügyelete alá tartozott. Mindkét testület az ország költségvetésében elkülönült önálló költségvetéssel rendelkezett. Felszerelésük, fegyverzetük, egyenruházatuk és szabályzataik egyediek voltak. A személyi állomány utánpótlása - a testőrségekhez hasonlóan — a fegyveres erök köréből került ki. ${ }^{\mathbf{1 0}}$

A koronaőrség, a képviselőházi őrség és a testőrségek ugyan katonailag szervezett őrtestületek voltak ugyan, azonban nem tartoztak a honvédelmi tárca alárendeltségébe, a haderő kötelékébe.

A testőrségek a föudvarmester irányítása alá tartoztak. Szükség esetén a szolgálattevő szárnysegéd is utasíthatta a testőrségeket. A testőrségek szolgálata számra a keretet az udvartartás müködését szabályozó „Udvari szolgálati rend” címü szabályzat tartalma biztosította. A korabeli testőrségek teendőiben a díszelgő jellegü tevékenység napjainkhoz képest sokkal erőteljesebb volt. A civilruhás feladatokat nem is a testőrök látták el, hanem a területileg illetékes rendvédelmi szervezetek detektív testületeinek csoportjai végezték ezen teendőket. Ez a szisztéma valósult meg a két világháború közötti időszakban is. ${ }^{11}$

Az uralkodót és közvetlen környezetét valamennyi testőrség az udvari rendhez igazodva örizte. Ferenc József azonban soha nem lehetett egyszerre egyidőben valamennyi testőrsége tevékenységének kedvezményezettje. A magyar testőrségek feladata a magyar király, az osztrák testőrségek feladata pedig az osztrák császár őrzése volt. Hiába töltötte azonban be mindkét közjogi méltóságot Ferenc József egyszemélyben. Magyarország területén ugyanis az uralkodó és kísérete biztonságáért a magyar testőrségek voltak felelősek. A Magyar Királyi Darabont Testőrség pedig — ellentétben a Magyar Királyi Nemesei Testőrséggel — a magyar Szent Korona alá tartozó országokon kívül eső terültre nem kísérhette el az uralkodót. Íly módon sohasem jöhetett létre az a helyzet, hogy az uralkodót valamennyi közjogi méltóságához szervezett testőrsége egyszerre védelmezze. A magyar Szent Korona alá tartozó területeken a magyar testőrségek kizárólagos jogosultsága természetesen nem zárta ki, hogy az uralkodó kíséretében a magyarországi utazásai alkalmával nem tartózkodhatott néhány fó a császári testőrségek tisztjei közül. Az uralkodó és kísérete védelmét azonban a Magyar Királyság területén a magyar testőrségek a magyarországi rendvédelmi testületekkel karöltve látták el. ${ }^{12}$

A Magyar Királyi Nemesi Testőrség tekintélyes múlttal rendelkező szervezet volt, amelyet Mária Terézia alapított. Ferenc József az önkényuralom időszakában a szervezetet feloszlatta ugyan, azonban a kiegyezést követően a testületet helyre állította. Ferenc József 1867. június 08-ai koronázásakor azonban a Nemesei Testőrség még nem lehetett jelen, mivel nem állt kellő idő rendelkezésre a szervezet létrehozására. Ezért a nemesi testőrséget 37 huszártiszt helyettesítette. A Magyar Királyi Magyar Királyi Nemesi Testőrség visszakapta az elődei által használt bécsi épületet az úgynevezett testőrpalotát. A jó fekvésủ nagyértékủ épületet a pártállam időszakában a magyar kormány — sajátos ideológiai megfontolásoktól vezérelve - lényegében elkótyavetélte. A nemesi testőrség esküszövege megegyezett az 1760. szeptember 11-én kelt királyi alapítólevélben foglalt eskü szövegével. 
A másik magyar testőrséget a Magyar Királyi Darabont Testőrséget 1904-ben hozták létre. Feladatát a királyi vár őrzése, illetve jeles ünnepségek alkalmával díszelgő teendők végzése alkotta. A Magyar Királyi Darabont Testőrség laktanyája a vár alatt a Palota téren állt. E terület neve jelenleg Dózsa tér. A testőr laktanya a Palota tér északi részén az Attila krt. sarkán állt. Bejárata az Attila krt. 4. szám alól nyílott. A Magyar Királyi Nemesei Testőrség és a Magyar Királyi Darabont Testőrség maradványaiból hozták létre 1920. augusztus 10-én a Magyar Királyi Testőrséget, miután HORTHY Miklós és családja a fövezérség Gellért szálló-beli szálláshelyéről a királyi várba költözött. A Magyar Királyi Testőrség a Magyar Királyi Darabont Testőrség laktanyáját kapta meg. Ezt az épületet nevezték el BESSENYEI Testör Laktanyának. ${ }^{13}$

Az erőteljesen díszelgő jellegű testőrségi feladatok eredményes megvalósítására egyértelműen a katonák voltak a legalkalmasabbak. A testőrségek személyi állományába való felvétel előfeltétele a katonai szolgálat volt. A testőrségekhez ép, egészséges testalkatú személyek kerülhettek, akik számára nem volt újdonság a katonai fegyelem és a díszelgésben is már járatosak voltak. A dualizmus időszakában a fegyveres szervezeteknél a kívánatos testmagasság minimum $160 \mathrm{~cm}$ volt. A testőrségeknél ezt a testmagasság minimumot $170 \mathrm{~cm}$-ben állapították meg. Az ép testalkat és a kellö testmagasság azonban önmagában kevés volt a felvételhez. A leendő testörökkel szembeni követelmény volt az egészséges fizikai és pszichikai állapot, valamint az erkölcsös életmód. A testmagasság kivételével a követelmények lényegében azonosak voltak a fegyveres erők tisztjeivel szemben támasztott követelményekkel. Testőrségi szolgálatra a fegyveres erök tisztjei jelentkezhettek. Közülük válogatták ki a legkiválóbbakat. Előnyt élveztek ugyan a harctéri sérüléssel rendelkezök, azonban ez a sérülés egyrészt nem gátolhatta őket a testőrségi szolgálat ellátásában, másrészt pedig nem csorbíthatta az ép testalkati követelményt. A testőr tiszteknek több nyelven kellett társalogni tudniuk, illetve elöírás volt számukra a táncolni tudás is. A testőrségekbe 45 évesnél idősebb személy nem kerülhetett, és 60 évesnél korosabb személy nem teljesíthetett szolgálatot. A fegyveres erö testőrségbe jelentkező tisztjeiről listát vezettek. A lista sorrendjét az alkalmasság figyelembe vételével alakították ki. A legalkalmasabb jelentkező állt a lista élén. A listát rendszeresen aktualizálták. ${ }^{14}$

A testőrség személyi állományára vonatkozó elóírások összhangban álltak az állami alkalmazottak szabályozásaival. Általános elv volt, hogy a szolgálati idő 40 év volt. 10 évi szolgálati idő a fizetés negyven százalékával azonos összegü nyugdíjra jogosította fel az állami alkalmazottat, amely minden további szolgálati évvel két százalékkal nőtt. Az aktív állami szolgálatban tölthető életkor felső határa 65 év volt. 65 év felett, vagy 40 évnél több szolgálati idővel senkit sem lehetett foglalkoztatni állami szférában. ${ }^{15}$

Ez a rendezési elv kezdetben a fegyveres szolgálatot ellátókra változtatás nélkül terjedt ki. A fegyveres szervezetek körében azonban tarthatatlan volt mivel - a civil életnél jelentösen megerőltetőbb szolgálatellátás miatt - már a nyugdíjba vonulás előtt elhunyt az érintettek jelentős része. Akik pedig megélték a nyugdíjukat döntő többségében a nyugdíjba vonulásukat követően néhány éven belül elhaláloztak. Ezért a fegyveres szolgálatot ellátó állami alkalmazottak szolgálati idejének első öt évét duplán számították a nyugdíjba vonulás, és a nyugdíj összegének kiszámítása tekintetében. Íly módon a civil állami alkalmazottakhoz képest öt évvel korábban, de azonos feltételekkel vonulhattak nyugdíjba a fegyveres szolgálatot ellátó állami alkalmazottak. ${ }^{16}$

A testőrségi szolgálatot ellátók esetében a rendezési elvek megegyeztek a haderőben fegyveres szolgálatot ellátó állami alkalmazottakéval. A testörök olyan katonák voltak, akik nem a véderöben, hanem az uralkodó katonai osztagaiban teljesítettek szolgálatot. Ebből a helyzetből fakadóan a testőrségbe belépőknek le kellett mondaniuk a haderőbeli ellátmányukról. Ez természetesen nem vonatkozhatott a már megszerzett nyugdíjjogosultságokra. A testőrök kizárólag testőrségi ellátmányban részesülhettek, amely kedvezőbb volt mint a haderőben. A testőrségi nyugdíjjogosultságukra vonatkozó szolgálati időszerzés a testőrségnél kezdődött. A testőrségeknél azonban „csupán” 60 éves korig teljesíthettek szolgálatot. Nyugdíjba vonulásuk alkalmával lényegében két nyugdíjra voltak jogosultak. Egyrészt arra, amire a haderőben szolgált évek után jogosultságot szereztek, másrészt pedig arra, amely a testőrségben teljesített szolgálati idejük alapján járt. Igaz ugyan, hogy mindkét nyugdíj a fizetés kisebb hányadát tartalmazta, mintha a testőr egy szervezetnél töltötte volna le aktív szolgálatát, azonban a magasabb testőrségi fizetés a különbözetet bőségesen pótolta, arról nem is beszélve, hogy a két nyugdíj összesített százalékos értéke is általában magasabb volt, mintha egy helyen szolgált volna csupán a nyugállományba vonuló testőr. Az aktív és a nyugállományú testörök valamennyi testőrségi járandóságát az udvar fedezte. A testőrök korábbi katonai szolgálata során keletkezett nyugellátási járandóságait pedig a haderő biztosította. ${ }^{17}$ 
A testörökre ugyan a katonákkal szemben támasztott általános elvárások vonatkoztak, azonban elöljárójuk a föudvarmester volt, aki egyben valamennyi testőrség ezredesi címét is viselte. Ettől eltekintve azonban a testőrségek kapitányai önálló parancsnokok voltak, a testőrségek független szervezetként müködtek. A testőrségek tagjai katonai rangot viseltek ugyan, azonban a testőrségi rangok a haderőbeli rangoknál magasabbak voltak. A Magyar Királyi Nemesi Testőrségnél a testőrkapitány haderőbeli altábornagynak, a testőr főhadnagy a haderő vezérőrnagyának, a testőr hadnagy a haderő ezredesének, a testőr őrmester a haderő őrnagyának, a testőr alőrmester a haderő századosának, a testőr a haderö hadnagyának, a testőrsegédtiszt a haderő századosának, a testőr orvos pedig a haderő ezredorvosának felelt meg. ${ }^{18}$

Némileg eltért a helyzet a Magyar Királyi Darabont Testőrségnél, ahol legénységi állomány is teljesített szolgálatot. Legénységi állomány tekintetében a testőrséghez kerülés életkori határa nem 45, hanem 35 év volt. A testőrségi elvárásoknak megfelelő legénység — a haderőben teljesített tényleges sorkatonai szolgálati idejének letöltése nyomán - lehetőséget kapott három éves testőri szolgálat vállalására, ezután pedig évente újíthatta meg szolgálati viszonyát. A testőr legénység a haderő altiszti rangjának a jellegével bírt, hasonlóan a csendőr legénységhez. ${ }^{19}$

A testörség legénységi állományára is kiterjedt az úgynevezett igazolványos altiszti fogalom. Azokat nevezték igazolványos altiszteknek, akik az államapparátusban olyan beosztásokat töltöttek be, amelyeknek a képesítési követelménye az érettséginél alacsonyabb volt és valamilyen - nem fegyelmi - okból kikerültek a fegyveres testületek tagjainak a köréből. Öket látták el a helyzetüket dokumentáló igazolvánnyal. Nevezetesen ezen igazolvánnyal rendelkező személyek számára az állami szervezetek tekintetében a megüresedett állások betöltését illetően elsőbbséget kellett biztosítani, ha egyébként a beosztáshoz kapcsolódó képesítési követelményeknek megfeleltek. ${ }^{20}$

Összességében bizton állítható, hogy a magyar testör szervezetek és tevékenységük — hasonlóan a császári testőrségekhez — nem tartoztak a közös ügyek hatáskörébe. A Magyar Királyság legfőbb közjogi méltóságát betöltő személy és közvetlen környezete védelmének ilyen jellegü biztosítása nem csupán egyszerü feladat besorolás volt. Elvi kérdést jelentett ugyanis, hogy milyen megítélésben részesül a testőrség, mint szervezet és a tevékenység. Az Osztrák-Magyar Monarchia testőrségi rendszere is egyértelmü bizonyítéka annak, hogy az államalakulat nem egységes birodalom két része, hanem két ország olyan szövetsége volt, amely bizonyos ügyeit közösen intézte.

A testőrségek függetlenek voltak az állam más alrendszereitől. A személyi állomány humán viszonyrendszerét azonban az állami alkalmazottakra vonatkozó szabályozásokra tekintettel alakították ki, azokkal összhangban müködtek.

A testör szervezetekben ugyan katonák teljesítettek szolgálatot, azonban nem tartoztak a haderő állományába. A testőrszervezetek személyi állománya lényegében kettős szürőn esett át mielőtt elkezdhette testőri szolgálatát, nevezetesen a katonai és a magasabb igényeket támasztó testőri rostán. Ebből fakadóan a dualista monarchia katonatársadalmának színe virága teljesített szolgálatot ezen szervezetekben.

\footnotetext{
Jegyzetek:

${ }^{1}$ Az uralkodó 1868. XI. 14-én az állam összességnek a megjelölésére „Osztrák-Magyar Monarchia” (ÖsterreichischUngarische Monarchie) „Osztrák-Magyar Birodalom” (Österreichisch-Ungarisches Reich) alternatív kifejezések használatát rendelte el a közös külügyminisztérium élére 1867. végén kinevezett — akkor már báróból grófi rangra emelt — Friedrich Ferdinánd BEUST Reichskanzler-nek írott levelében. BEUST-nak azért adományozott az uralkodó birodalmi kancellári címet, mert egyben a HABSBURG-ház minisztere is volt. A másik két közös miniszter a közös pénzügyminiszter és a közös hadügyminiszter Reichsminister címet kapott. A közös ügyek tárcáinak irányítói azonban nem alkottak közös kormányt. A közös minisztertanácson részt vett a két társország miniszterelnöke és a közös ügyek miniszterei, valamint a téma által érintett osztrák és magyar minisztériumok vezetői. Ha a közös minisztertanácson az uralkodó is részt vett azt koronatanácsnak nevezték.

GALÁNTAI: 118-121.p.

${ }^{2}$ Az osztrák és a magyar kiegyezési törvények nem két birodalomrész, illetve két ország közötti szerződés becikkelyezései, hanem az uralkodó és a magyar országgyülés, illetve az uralkodó és a Reichsrat közötti egyeztetések eredményei, amelyek szövegükben is eltérnek ugyan egymástól bár tartalmukban azonosak.

1867/XII.tc. ; 1867.Nr.146.

${ }^{3}$ GALÁNTAI: op.cit. 89-135.p.

${ }^{4}$ A jogeljátszás elméletének tarthatatlanságát DEÁK Ferenc vezette le. DEÁK: 170-171.p.

${ }^{5}$ A ,,vezérleti” (Leitung) jogba a hadüzenet joga is beletarozott. A ,vezényleti” (Führung) jogba a fegyveres erő irányítása tartozott, azt az uralkodó bármikor bárhová küldhette. A „belszervezeti” (innere Organisation) jogba az összes belső ügy beletartozott, mint például a szervezeti felépítés meghatározása, a szolgálati nyelv megállapítása, a tisztek kinevezése, a fegyelmezés stb.

1868/XL.tc. ； 1868/XLI.tc. ； 1868/XLII.tc. GALÁNTAI : op.cit.
} 


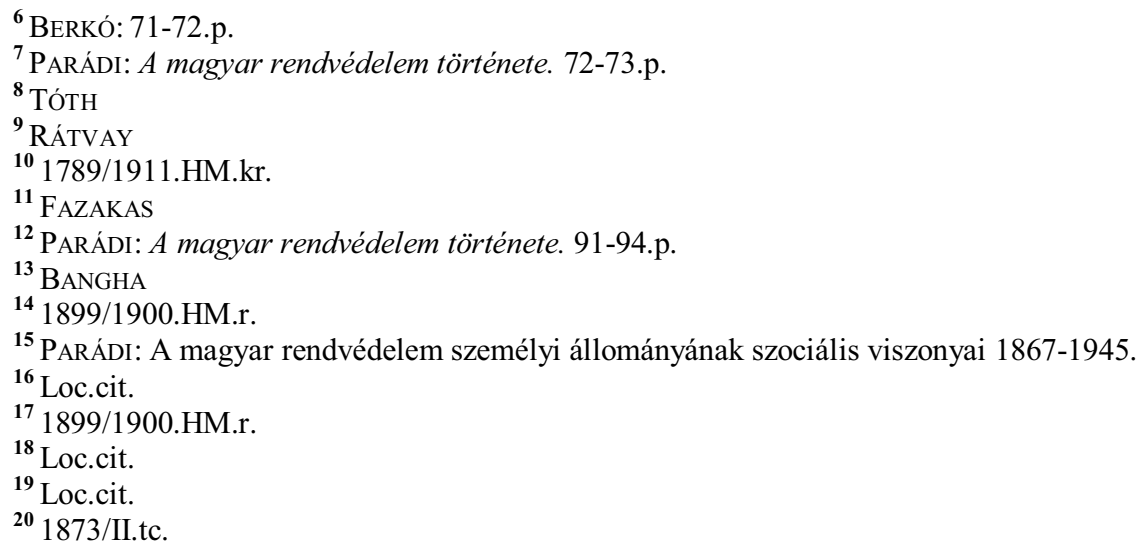

Jegyzetekben alkalmazott röviditések:

\section{MONOGRAFIAK}

BANGHA

BERKÓ

DEÁK

GALÁNTAI

PARÁDI: A magyar rendvédelem története.

RÁTVAY

\section{TANULMÁNYOK}

FAZAKAS

PARÁDI: A magyar rendvédelem személyi állományának szociális viszonyai $1867-1945$.

То́тн

\section{JOGSZABÁLYOK 1867/XII.tc.}

1867.Nr.146.

1868/XL.tc.

1868/XLI.tc

1868/XLII.tc

1873/II.tc.

1899/1900.HM.r.

1789/1911.HM.kr.
— Bangha Ernő: A Magyar Királyi Testörség 1920-1941. Budapest, 1990, Európa. 403 p. HU-ISBN 9630752158.

- Berkó István (szerk.): A Magyar Királyi Honvédség története 1868-1918. Budapest, 1928, Magyar Királyi Hadtörténeti Levéltár. 601 p.

- DEÁK Ferenc: Adalékok a magyar közjoghoz. Pest, 1865, s.n.

- Galántai József: A Habsburg-monarchia alkonya. Osztrák-magyar dualizmus 18671918. Budapest, 1985, Kossuth. 387 p. HU-ISBN 9630925893.

- PARÁDI József et al. (szerk.) : A magyar rendvédelem története. Budapest, 1996², Osiris. 367 p. HU-ISBN 9630479583.

- RÁtvay Géza: A koronaőri intézmény a magyar alkotmányban. Budapest, 1898, Atheneum.

- FazAKas László: A Magyar Királyi Testőrség, a Magyar Királyi Koronaőrség és a Magyar Királyi Képviselőházi Örség a két világháború között. Rendvédelem-történeti Füzetek (Acta Historiae Preasidii Ordinis), V.évf. (1995) 6.sz. 27-38.p. HU-ISSN 12166774. A tanulmány korábbi változata 1994. októberében Budapesten hangzott el a Szemere Bertalan Magyar Rendvédelem-történeti Tudományos Társaság által szervezett rendvédelem-történeti tudományos konferenciasorozatnak a „A két világháború közötti Magyar Királyság rendvédelme” című VI. konferenciáján. A publikált tanulmány az előadás javított, bővített és átdolgozott változata.

PARÁD Józsefi: A magyar rendvédelem személyi állományának szociális viszonyai 1867-1945. Rendvédelem-történeti Füzetek (Acta Historiae Preasidii Ordinis), XV.évf. (2008) 17.sz. 57-64.p. HU-ISSN 1216-6774. A tanulmány korábbi változata 2003. november 11-én Budapesten hangzott el a Szemere Bertalan Magyar Rendvédelemtörténeti Tudományos Társaság által szervezett rendvédelem-történeti tudományos konferenciasorozatnak a „A rendvédelem humán viszonyai” címü XVII. konferenciáján. A publikált tanulmány az előadás javított, bővített és átdolgozott változata.

- Tóтн László: A képviselőházi Örség születésének története. Rendvédelem-történeti Füzetek (Acta Historiae Preasidii Ordinis), IV.évf. (1994) 5.sz. 36-41.p. HU-ISSN 12166774. A tanulmány korábbi változata 1993. szeptember 21-én Budapesten hangzott el a Szemere Bertalan Magyar Rendvédelem-történeti Tudományos Társaság által szervezett rendvédelem-történeti tudományos konferenciasorozatnak a „Háború, forradalom, trianon” címü V. konferenciáján. A publikált tanulmány az előadás javított, bővített és átdolgozott változata.

— 1867/XII.tc. a Magyar Korona országai és az Ö Felsége uralkodása alatt álló többi ország között fennforgó közös érdekü viszonyokról és ezek elintézésének módjáról.

- 1867.Nr.146. Betreffend die allen Lindärn der Österreichischen Monarchie gemeinsamen Angelegenbeiten und die Art ichrer Behandlung.

- 1868/XL.tc. a véderőröl.

- 1868/XLI.tc. a honvédségröl.

- 1868/XLII.tc. a népfelkelésröl.

- 1873/II.tc. a kiszolgált altisztek alkalmazásáról.

— 1899/1900.HM.r. szervi határozványok a császári és királyi testőrségek számára.

— 1789/1911.HM.kr. a Magyar Királyi Koronaőrség szervezeti és szolgálati szabályzata. 
Az osztrák császár és a magyar király udvartartási költségei

I.sz. melléklet

\begin{tabular}{|c|c||c||c|c|}
\hline Tárgyév & $\begin{array}{c}\text { Az osztrák császár } \\
\text { udvartartási } \\
\text { költsége }\end{array}$ & $\begin{array}{c}\text { Ausztria } \\
\text { költségvetésének \%-a }\end{array}$ & $\begin{array}{c}\text { A Magyar Király } \\
\text { udvartartási } \\
\text { költsége }\end{array}$ & $\begin{array}{c}\text { Magyarország } \\
\text { költségvetésének \%-a }\end{array}$ \\
\hline $\mathbf{1 8 6 8}$ & $3250000 \mathrm{Ft}$ & $1,1 \%$ & $3250000 \mathrm{Ft}$ & $2,5 \%$ \\
\hline $\mathbf{1 8 6 9}$ & $3250000 \mathrm{Ft}$ & $3250000 \mathrm{Ft}$ & \\
\hline $\mathbf{1 8 8 0}$ & $4650000 \mathrm{Ft}$ & & $4650000 \mathrm{Ft}$ & \\
\hline $\mathbf{1 9 1 0}$ & $4650000 \mathrm{Ft}$ & $1 \%$ alatt & $4650000 \mathrm{Ft}$ & $1 \%$ alatt \\
\hline $\mathbf{1 9 1 3} *$ & 11300000 korona & $1 \%$ alatt & $11300000 \mathrm{korona}$ & $1 \%$ alatt \\
\hline
\end{tabular}

*A valutareform nyomán 1 forintnak 2 korona felelt meg.

Forrás! GALÁNTAI József: A Habsurg-monarchia alkonya. Osztrák-magyar dualizmus 1867-1918. Budapest, 1985, Kossuth, 91-94.p. 